UDC 504.5

DOI: 10.21668/health.risk/2019.3.04.eng

\title{
NANO- AND MICRO-PARTICLES CONCENTRATIONS IN WORKING AREA AIR AT GALVANIC PRODUCTION: PILOT RESEARCH
}

\author{
K.S. Golokhvast ${ }^{1}$, K.Yu. Kirichenko ${ }^{1}$, P.F. Kiku ${ }^{1}$, N.V. Efimova ${ }^{2}$, M.F. Savchenkov ${ }^{3}$, \\ I.A. Vakhnyuk ${ }^{1}$, D.Yu. Kosyanov', S.A. Medvedev ${ }^{4}$, V.P. Soparev', V.A. Drozd ${ }^{1}$ \\ ${ }^{1}$ Far Eastern Federal University, 8 Sukhanova Str., Vladivostok, 690091, Russian Federation \\ ${ }^{2}$ East-Siberian Institute of Medical and Environmental Research, 3A, 12A Mikroraion Str., Angarsk, 665827, \\ Russian Federation \\ ${ }^{3}$ Irkutsk State Medical University, 2 Krasnogo Vosstania Str., Irkutsk, 664003, Russian Federation \\ 4“Izumrud” joint-stock company, 65 Russkaya Str., Vladivostok, 690105, Russian Federation \\ 5“Dalpribor" PLC, 46/50 Borodinskaya Str., Vladivostok, 690105, Russian Federation
}

Electrochemical processes that involve making protective coats at contemporary galvanic productions are widely spread in various industries. As chemically active solutions and heavy metals are usually applied in galvanic production, it can be ranked among hazardous ones. Our research goal was to examine morphometric parameters of nano- and micro-particles that were detected in working area air at enterprises where galvanic baths and electrochemical processes were applied.

To perform a complex examination of particle-size distribution and concentration of a galvanic aerosol (GA) in working area air, we applied a combined procedure that included:

1) measuring qualitative structure of particulate matter $\left(\mathrm{mg} / \mathrm{m}^{3}\right)$ according to ISO 21501-4 in order to determine concentrations of $P M_{0.3}, P M_{0.5}, P M_{1}, P M_{3}, P M_{5}$, and $P M_{10}$ with a portable laser meter;

2) measuring mass concentrations of $P M_{10}$ according to the European Standard for determining particulate matter EN 12341:2014;

3) measuring particle-size structure of particulate matter via deposition with laser granulometry.

Quantities of particles that belonged to $P M_{0,3}$ fraction were more than 10,000 times higher in working area air inside a galvanic workshop that quantities of those belonging to $P M_{10}$ fraction. Maximum quantities of particles were detected near a nickel-plating bath. Mass concentration of $P M_{10}$ fraction amounted to $0.04 \pm 0.0001 \mathrm{mg} / \mathrm{m}^{3}$. Contents of particles with their size exceeding $700 \mu \mathrm{m}$ accounted for 30-90\% of the overall quantities of particles at most examined points; particles with their size being less than $10 \mu \mathrm{m}$ were detected only in an area where aluminum was being hardened.

Quality of working area air at galvanic production doesn't fully provide safe working conditions due to ultra-thin fractions prevalence in industrial aerosols; it can result in so called "sub-threshold effects" causing bronchopulmonary diseases.

Key words: working area, galvanic production, working conditions, air quality, industrial aerosols, nano-and microparticles.

(c) Golokhvast K.S., Kirichenko K.Yu., Kiku P.F., Efimova N.V., Savchenkov M.F., Vakhnyuk I.A., Kosyanov D.Yu., Medvedev S.A., Soparev V.P., Drozd V.A., 2019

Kirill S. Golokhvast - Doctor of Biological Sciences, Corresponding Member of the Russian Academy of Education, Professor of the Russian Academy of Sciences Professor at the Department of Life Safety in the Technosphere (e-mail: droopy@mail.ru; tel.: +7 (924) 126-13-13; ORCID: https://orcid.org/0000-0002-4873-2281).

Konstantin Yu. Kirichenko - Candidate of Biological Sciences, Researcher at the Research and Educational Center for Nanotechnologies (e-mail:Kirichenko2012@gmail.com; tel.: +7 (950) 285-76-57; ORCID: https://orcid.org/0000-0002-2715-3758).

Pavel F. Kiku - Doctor of Medical Sciences, Candidate of Technical Sciences, Professor, Head of the Department for Public Health and Preventive Medicine (e-mail: lme@list.ru; tel.: +7 (902) 555-48-91; ORCID: https://orcid.org/my-orcid/00000003-3536-8617).

Nataliya V. Efimova - Doctor of Medical Sciences, Professor, Leading Researcher at the Laboratory of Ecological and Hygienic Research (e-mail: medecolab@inbox.ru; tel.: +7 (914) 892-19-47; ORCID: http://orcid.org/0000-0001-7218-2147).

Mikhail F. Savchenkov - Doctor of Medical Sciences, Academician of the Russian Academy of Sciences, Professor, Professor of the Common Hygiene Department (e-mail: smf36@mail.ru; tel.: +7 (395) 224-38-43; ORCID: http://orcid.org/0000-0002-1246-8327).

Igor A. Vakhnuk - Postgraduate Student (e-mail: vahnuk86@mail.ru; tel.: +7 (904) 628-10-88).

Denis Y. Kosyanov - Candidate of Technical Sciences, Senior Researcher at the Laboratory of Electronic Structure and Quantum-Chemical Modeling, Department of General and Experimental Physics (e-mail: kosianov.diu@dvfu.ru; tel.: +7 (984) 156-64-80).

Stanislav A. Medvedev - Deputy Director responsible security at «Izumrud» Stock Company (e-mail: MedvedevStanislav-79@mail.ru; tel.: +7 (908) 448-85-35).

Viktor P. Soparev - Deputy Chief Technologist at «Dalpribor» Public Stock Company (e-mail: soparev@mail.ru; tel.: +7 (914) 7959870).

Vladimir A. Drozd - Radiation Safety Engineer at the Research and Educational Center for Nanotechnologies (e-mail: v_drozd@mail.ru; tel.: +7 (924) 733-12-7). 
Electrochemical processes at contemporary galvanic production are applied to make protective coats and can be met in various branches including defense and aerospace industries. Galvanic production is considered to be hazardous due to chemically active solutions and heavy metals being widely used in it. As per data provided by Rosstat a specific weight of workers employed at adverse and (or) hazardous productions grows annually $[1,2]$. As is well known, hazardous substances penetrate a worker's body not only through the respiratory tracts but also through the skin, ears, eyes, and other unprotected parts of a body [3]. Permanent exposure to negative factors existing at galvanic production causes occupational diseases, mostly in the respiratory organs and upper respiratory tracts, circulatory system, and the musculoskeletal system when working experience at such a production is from 10 to 15 years. Suspensions rich with nano- and micro-particles of heavy metals essentially occur in the air in a workshop where electrochemical processes take place; it is a significant factor for creating programs aimed at protecting workers' health. It is necessary to implement efficient prevention activities and apply protection means for workers employed at hazardous productions and workers with allied occupations if we want to reduce a number of disease cases and risks of lethal outcomes. The task can be solved only after assessing morphometric parameters of nano- and micro-particles as well as properties of particles in an industrial aerosol that occurs in a galvanic workshop.

Nano- and micro-sized suspensions in the atmosphere are detected at points that are quite remote from industrial buildings [4-6], they exert considerable influence on climate in industrial centers [7], and technogenic particles account for $45 \%$ out of overall aerosol particles [8]; nevertheless, contamination of working area air at galvanic production and adjoining territories with nano- and micro-sized suspensions hasn't been given relevant attention. If we fail to assess significance and hazards caused by nanotechnological contamination, it can cre- ate health risks for population and makes certain areas less socially and economically attractive [9]. Working conditions have a key role in protecting population health and health of welders in particular. Microclimate at a working place matters a lot as a person consumes $15 \mathrm{~kg}$ of air per day. Unsatisfactory microclimatic parameters cause occupational diseases. Particles with their size being up to $10 \mu \mathrm{m}$ are the most hazardous for human health due to their ability to cause respiratory diseases [10-12].

Previously we detected nano- and microparticles within sanitary protection zones around industrial enterprises that had galvanic workshops in their structure [5]. In particular, we'd like to mention suspended $\mathrm{Fe}$ and $\mathrm{Cr}$ particles with their diameter being equal to $10-120 \mathrm{~nm}$ and their share accounting for up to $76 \%$; however, we couldn't detect a source and a mechanism of their occurrence.

Issues related to nano-particles penetrating working area air remain outstanding. In particular, there are no criteria for assessing exposure to nanoparticles; as the chemical structure of particulate matter is usually a multi-component one, there are not enough data on potential toxicological effects produced by exposure to them and it creates significant difficulties for experts who try to substantiate hygienic standards in the sphere.

Our research goal was to perform complex analysis of nano- and micro-particles contents in working area air as a factor causing health risks for workers employed at enterprises where electroplating baths and electrochemical processes were applied.

Data and methods. We performed our research in a galvanic workshop where basic technological processes were aluminum clarification and pickling; sulfuric anodic treatment; chemical and electric aluminum degreasing; removal of sludges after pickling; non-ferrous metals pickling; chrome and nickel plating. To perform a complex examination of particle-size distribution and concentration of a galvanic aerosol (GA) in working area air, we applied a combined procedure that included: 
1) measuring quantitative structure of particulate matter $(\mathrm{mg} / \mathrm{m} 3)$ according to ISO 21501-4 in order to determine concentrations of PM0.3, PM0.5, PM1, PM3, PM5, and PM10 with a portable laser meter;

2) measuring mass concentrations of PM10 according to the European Standard for determining particulate matter EN 12341:2014;

3) measuring particle-size structure of particulate matter via deposition with laser granulometry.

1. Measuring quantitative structure of particulate matter. To quantitatively analyze and determine particles concentrations in working area air we applied a hand laser Aero Trak Handheld Particle Counter 9306 (the USA). The model 9306 conforms to all the requirements fixed in ISO 21501-4. Samples at each point were taken during 1 minute. Overall air volume that passed through the device amounted to $2.83 \mathrm{1} / \mathrm{min}$ and it was within its recommended functioning modes. Samples were taken at 1.5 meters height as it corresponded to a height at which a person usually breathes; all sampling points were located directly above an open electrolyte of an electroplating bath. Overall, we examined 11 electroplating baths in our experiment which were included into technological processes at three production lines: a line where aluminum was being prepared; a line where non-ferrous metals were being prepared; and a line where protection covers were being made. The list of sampling points and electrolytes applied in production processes is given in Table 1.

We performed 5 measurements for each type of an electroplating bath $(\mathrm{N}=60)$ in our experiment.

2. Measuring mass concentrations of particulate matter. To determine concentrations of aerosol particles $\left(\mathrm{mg} / \mathrm{m}^{3}\right)$ in working area air in a galvanic workshop, we took a series of samples near stationary electroplating baths. We chose a gravimetric procedure to measure concentrations of GA particles and used an aspiratory LVS 3.1 type sampler (Ingeniero Nobert Derenda, Germany). This sampler has a nozzle for sampling $\mathrm{PM}_{10}$ fraction and is also equipped with $47 \mathrm{~mm}$ nylonbased filters Nylon 66 Membranes without connections and their working surface diameter being $47 \mathrm{~mm}$ (SUPERLCOUSA). Flowing capacity of the filters amounted to $0.45 \mu \mathrm{m}$. Thereby, an examined range of particulate matter varied from $0.45 \mu \mathrm{m}$ to $10 \mu \mathrm{m}$. We chose $10 \mu \mathrm{m}\left(\mathrm{PM}_{10}\right)$ as an upper limit of the particles fraction as it is well in line with modern trends in control over particulate matter in the atmosphere [13-16].

Table 1

Technological processes at a galvanic workshop

\begin{tabular}{|c|l|c|c|}
\hline No. & \multicolumn{1}{|c|}{ A technological processes } & Electrolyte structure & $\begin{array}{c}\text { Production line } \\
\text { for preparing }\end{array}$ \\
\hline 1 & Background territory (offices) & - & - \\
\hline 2 & Aluminum clarification & $\mathrm{HNO}_{3}$ & Aluminum \\
\hline 3 & Aluminum pickling & $\mathrm{NaOH}$ & Aluminum \\
\hline 4 & Sulfuric anodic treatment & $\mathrm{H}_{2} \mathrm{SO}_{4}$ & Aluminum \\
\hline 5 & Aluminum degreasing & $\mathrm{Na}_{2} \mathrm{CO}_{3} ; \mathrm{Na}_{3} \mathrm{PO}_{4}$ & Aluminum \\
\hline 6 & Chemical degreasing & $\mathrm{Ja}_{0} \mathrm{Mu}_{2} 203$ & Non-ferrous metals \\
\hline 7 & Electrical degreasing & $\mathrm{Na}_{2} \mathrm{CO}_{3} ; \mathrm{Na}_{3} \mathrm{PO}_{4}$ & Non-ferrous metals \\
\hline 8 & Removal of sludges after pickling & $\mathrm{Cr}_{2} \mathrm{O}_{3} ; \mathrm{H}_{2} \mathrm{SO}_{4} ; \mathrm{NaCl}$ & Non-ferrous metals \\
\hline 9 & Non-ferrous metals pickling & $\mathrm{HNO}_{3} ; \mathrm{H}_{2} \mathrm{SO}_{4} ; \mathrm{HCl}$ & Non-ferrous metals \\
\hline 10 & Chrome plating & $\mathrm{H}_{2} \mathrm{CrO}_{4} ; \mathrm{H}_{2} \mathrm{SO}_{4}$ & Non-ferrous metals \\
\hline 11 & Nickel plating & $\mathrm{NiSO}_{4} ; \mathrm{MgSO}_{4} ; \mathrm{Na}_{2} \mathrm{SO}_{4} ; \mathrm{NaCl} ; \mathrm{H}_{3} \mathrm{BO}_{3}$ & Non-ferrous metals \\
\hline 12 & Chemical nickel plating & $\mathrm{NiSO}_{4} ; \mathrm{MgSO}_{4} ; \mathrm{Na}_{2} \mathrm{SO}_{4} ; \mathrm{NaCl} ; \mathrm{H}_{3} \mathrm{BO}_{3}$ & Non-ferrous metals \\
\hline
\end{tabular}


Table 2

Particle size distribution for an industrial aerosol in a galvanic workshop, units $/ 100 \mathrm{~cm}^{3}$

\begin{tabular}{|c|l|c|c|c|c|c|c|}
\hline № & \multicolumn{1}{|c|}{ Sampling point } & $\mathrm{PM}_{0,3}$ & $\mathrm{PM}_{0,5}$ & $\mathrm{PM}_{1}$ & $\mathrm{PM}_{3}$ & $\mathrm{PM}_{5}$ & $\mathrm{PM}_{10}$ \\
\hline 0 & Background territories (offices) & 159,643 & 29,317 & 2,318 & 196 & 74 & 10 \\
\hline 1 & Aluminum clarification & $19,247,204$ & $3,126,713$ & 269,112 & 42,071 & 18,171 & 2,282 \\
\hline 2 & Aluminum pickling & $18,774,926$ & $2,858,021$ & 234,399 & 34,086 & 13,895 & 1,711 \\
\hline 3 & Sulfuric anodic treatment & $18,758,289$ & $3,134,410$ & 286,763 & 48,169 & 20,977 & 2,938 \\
\hline 4 & Aluminum degreasing & $28,703,393$ & $6,005,978$ & 338,080 & 35,892 & 14,768 & 1,766 \\
\hline 5 & Chemical degreasing & $16,610,093$ & $4,995,215$ & $1,119,675$ & 459,242 & 273,288 & 44,287 \\
\hline 6 & Electrical degreasing & $23,821,193$ & $4,836,159$ & 290,667 & 36,512 & 15,388 & 2,186 \\
\hline 7 & Removal of sludges after pickling & $19,961,226$ & $3,427,211$ & 250,587 & 33,378 & 13,710 & 1,666 \\
\hline 8 & Non-ferrous metals pickling & $20,526,593$ & $3,053,826$ & 237,555 & 30,997 & 12,420 & 1,600 \\
\hline 9 & Chrome plating & $10,932,963$ & $1,671,387$ & 181,983 & 24,534 & 9,946 & 1,150 \\
\hline 10 & Nickel plating & $20,245,996$ & $3,689,208$ & 337,626 & 33,953 & 12,332 & 1,180 \\
\hline 11 & Chemical nickel plating & $31,279,133$ & $10,266,759$ & 715,403 & 22,772 & 6,628 & 406 \\
\hline
\end{tabular}

Prior to sampling the filters had been dried in TC-1/20 thermostat (Russia) for 24 hours at $40{ }^{\circ} \mathrm{C}$; after that each filter was weighted 5 times with an electronic balance Sartorius (Germany) and a mean value for a weight was determined. Readings were taken at 5 points in a galvanic workshop; those points were located at a distance from 1 to 5 meters away from stationary nickel plating baths as such baths were sources of the most toxic particles. The nozzle was fixed at 1.5 meters height as it corresponded to a height at which a person usually breathes. We obtained 10 sets of data for each type of an electroplating bath $(\mathrm{N}=50)$ in our experiment.

3. Measuring particle-size structure of particulate matter via deposition. To perform particle-size analysis for particles contained in working area air, we took samples via the following procedure: we placed sterile plastic containers on the workshop floor where workers performed their tasks in a workshop; a volume of each container amounted to 2.7 liters and they were all filled with distilled water (this water treatment procedure completely removes any particulate matter from water) obtained with DE-4-02-EMO water distillation device ("Electromedoborudovanye" LLC, Saint Petersburg, Russia). Particles settled into open containers. The procedure was chosen due to a possibility to collect the whole range of nano- and micro-particles as it is not the case with any other alternative method (any applied filter has a minimal size equal to 430 $\mathrm{nm}$ and it means that smaller particles pass through it freely). Prior to the experiment all the containers had been thoroughly washed, firstly with running water, and then twice with distilled water; after it the containers were filled with $600-800 \mathrm{ml}$ of distilled water which amounted to $1 / 3$ of their overall volume. We wrote down a denomination of an electroplating bath for each sample as well as a date and time at which it was taken.

Our experiment lasted for 8 hours as it was equal to working shift duration in the chosen workshop. The containers were placed close to operating stationary electroplating baths and were open at 8 a.m. just as a working shift started. As the shift ended at 17 p.m., the containers were tightly closed, marked and transported to a laboratory for further research.

Results were statistically processed with "Statistica 10.0" software package; we assessed statistical significance of parameters and discrepancies between examined samplings as per Student's t-test taking into account a type of values distribution.

Results and discussion. Having examined particle-size distribution, we detected that the smallest particles prevailed absolutely (Table 2).

A quantity of $\mathrm{PM}_{0,3}$ (particles smaller than $0.3 \mu \mathrm{m}$ ) was more than 10,000 times 
higher than a quantity of $\mathrm{PM}_{10}$. Maximum particles concentrations were detected near a nickel plating bath, a stationary one with treatment temperature being $15-25{ }^{\circ} \mathrm{C}$. The bath was applied for electrochemical treatment of metals and was equipped with ventilation systems; it was heated by a direct current source. As samples were taken directly above contents of stationary electroplating baths, the results we obtained prove that primary particles in industrial aerosols which occur during electrochemical processes tend to have very small sizes. Basically, primary particles tend to be smaller than $0.3 \mu \mathrm{m}$.

We measured concentrations of particulate matter with particles sizes being less than $10 \mu \mathrm{m}$ at a distance $1-3$ meters away from stationary baths for chemical nickel plating, nickel plating, and an aluminum preparation line; our measuring revealed that particles concentrations were within $0.0417 \pm 0.0001$ $0.0438 \pm 0.0002 \mathrm{mg} / \mathrm{m}^{3}$ range and didn't change significantly at an examined distance.

At present, both in the RF and worldwide, there are no standards for assessing nano- and micro-particles contents in working area air at galvanic production. But still, some research works $[1,4,5$, and 17] indicate that particles with different sizes occur in the air inside galvanic workshops. Our particle size analysis revealed that particles with their size being less than $10 \mu \mathrm{m}$ prevailed in working area air; among them the most frequent particles were ultrathin ones or $\mathrm{PM}_{0,3}$. The smallest particles of heavy metals in industrial aerosols are able to penetrate deep into the respiratory organs and spread further all over a body [11] causing chronic diseases in the respiratory tracts and overall decrease in working capacity.

As there are no data on elemental structure of GA mixture in electroplating production, it is impossible to hygienically assess the results we have obtained in our experiments. We should note that standards for permissible nano-particles contents differ greatly for their types; thus, for example, the standard for single-shell carbon nanotubes is
$0.007 \mathrm{mg} / \mathrm{m}^{3}$, and that for titanium oxide nanoparticles is $0,3 \mathrm{mg} / \mathrm{m}^{3}$. Given that, it is necessary to perform further research and standardize contents of nanoparticles with various chemical structures.

The results of particle size analysis performed on particulate matter via deposition indicate that there are two types of suspension occurring at electroplating production. The Figures show typical graphs of particles distribution as per their sizes: first, prevailing particles with their size being less than $10 \mu \mathrm{m}$ (Figure 1) and, secondly, with prevailing particles sized more than $700 \mu \mathrm{m}$ (Figure 2). The first variant occurs only at an aluminum hardening line (2 samples out of 12). We should note that the greatest specific weight of particles smaller than $10 \mu \mathrm{m}(88.2 \%)$ was detected in a sample taken at an aluminum hardening line near a stationary bath for aluminum degreasing. Samples taken at other points contained from $30 \%$ to $90 \%$ particles which were bigger than $700 \mu \mathrm{m}$. We should also note that there were practically no particles with their sizes ranging from $50 \mu \mathrm{m}$ to $400 \mu \mathrm{m}$ in the examined samples.

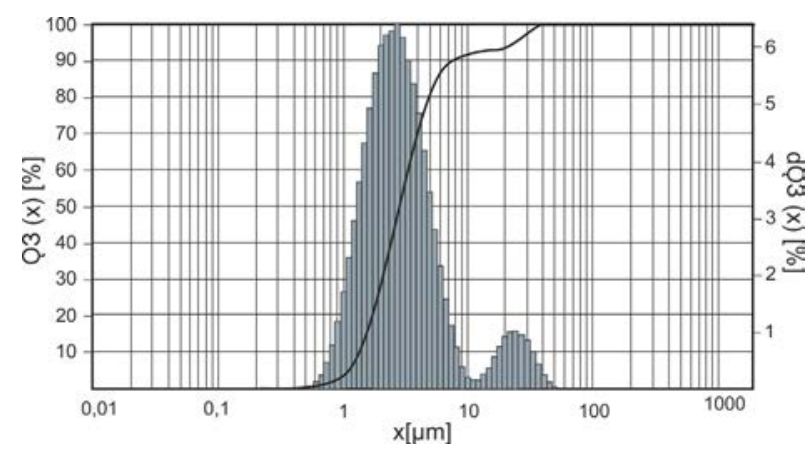

Figure 1. Particle size distribution in Sample No. 4 (aluminum degreasing)

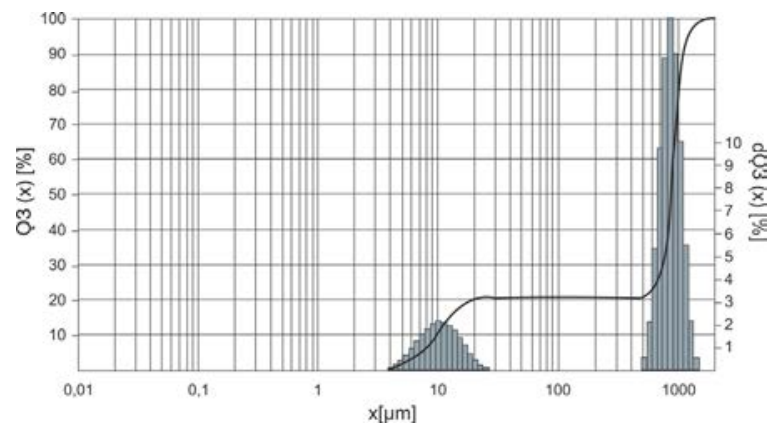

Figure 2. Particle size distribution in Sample No. 12 
Data obtained via analysis of particle size distribution indicate that there is quantitative prevalence of large particles. The detected discrepancy between results of two different procedures which we applied is due to both different sampling techniques and particles behavior in the air. When samples are taken directly above electroplating baths, $\mathrm{PM}_{0,3}$ are detected most frequently. Primary particles with their size being smaller than $0.3 \mu \mathrm{m}$ occur above stationary baths during a working shift, turn into suspended state, stick together, and form large aggregates and clusters; as such aggregates and clusters grows bigger than $700 \mu \mathrm{m}$, they settle. We should note that measuring itself was limited by flow capacity of chosen filters which was $0.45 \mu \mathrm{m}$; that is, particulate matter that were smaller flew through the aspirator freely and didn't settle on the filter. Therefore, we should assume that if filters with lower flow capacity are applied in an experiment, obtained values can be higher than ours. However, it is a common thinking that ultrathin particles, despite their significant quantity, make a very small contribution into the overall weight of particulate matter in the air [18].

Our pilot research proves there is a high quantitative concentration of particulate matter in a galvanic workshop with predominant particles sized up to $0.3 \mu \mathrm{m}$; such particles are the most hazardous for human health as they can cause bronchopulmonary diseases, including industrially induced and occupational pathologies. Workers should be well aware of the risks as it will allow better control over exposure to such particles.
But at the same time, the obtained results have some uncertainties. As PM properties depend not only on sizes but also on chemical structure, we can't compare obtained concentrations with any standard at the moment. There should be further research; in particular, it is necessary to determine chemical and qualitative structure of GA. When the task is solved, it will allow performing a toxicological experiment and developing hygienic standards for nano- and micro-particles contents in working area air [19-21].

Conclusion. We examined stationary nickel plating and aluminum preparation lines and showed that high $\mathrm{PM}_{10}$ mass quantity in working are air was caused by occurrence of large aggregates made of primary finest particles suspended in working are air in a galvanic workshop. Absolute prevalence of finest $\mathrm{PM}_{0,3}$ (data obtained with a portable particle counter) and a consequent decrease in their quantity (as per measuring particles size distribution) was caused by aggregation of particles in the air during a working shift and a prevailing gas component in an industrial aerosol. The results of our research, together with those obtained in further one, can be applied for consequent correct assessment of exposure to particulate matter distributed in working area air. The results can also be applied in epidemiologic research on workers' health.

Funding. The RF President Grant for young scientists MK-2461.2019.5.

Conflict of interests. The authors declare there is no any conflict of interests.

\section{References}

1. Trushkova E.A., Gorbatkova A.V., Vel'chenko A.A. Gigienicheskaya otsenka uslovii truda gal'vanikov [Hygienic assessment of working conditions for galvanizers]. Aktual'nye napravleniya innovatsionnogo razvitiya zhivotnovodstva i sovremennye tekhnologii proizvodstva produktov pitaniya: sbornik materialov mezhdunarodnoi nauchno-prakticheskoi konferentsii. Moscow, 2016, pp. 306-309 (in Russian).

2. Omelchenko E.V., Trushkova E.A., Sidelnikov M.V., Pushenko S.L., Staseva E.V. Algorithm Research Exposure Dust Emissions Enterprises of Building Production on the Environment. IOP Conference Series: Earth and Environmental Science, 2017, vol. 50, no. 1, 6 p. DOI: 10.1088/1755$1315 / 50 / 1 / 012018$

3. Halliday-Bell J., Palmer K., Crane G. Health and safety behaviour and compliance in electroplating workshops. Occup. Med. (Lond), 1997, vol. 47, no. 4, pp. 237-240. DOI: 10.1093/occmed/47.4.237 
4. Kiryushina N.Yu. Osobennosti ochistki stochnykh vod gal'vanicheskikh proizvodstv of ionov tyazhelykh metallov shlakom elektrostaleplavil'nogo proizvodstva [Peculiarities related to removing heavy metals ions from sewage of galvanic productions with slag from electrical steel-smelting production]. Vodoochistka, 2013, no. 6, pp. 44-58 (in Russian).

5. Golokhvast K.S., Shvedova A.A. Galvanic Manufacturing in the cities of Russia: Potential source of ambient nanoparticles. PLOS One, 2014, vol. 9, no. 10, pp. e110573. DOI: 10.1371/journal.pone.0110573

6. Guo P.R., Lei Y.Q., Zhou Q.L., Wang C., Pan J.C. Distribution Characteristics of Heavy Metals in Environmental Samples Around Electroplating Factories and the Health Risk Assessment. Huan Jing Ke Xue, 2015, vol. 36, no. 9, pp. 3447-3456.

7. Belan B.D., Simonenkov D.V., Tolmachev G.N. Chemical composition of industrial aerosol in some regions. Chemical Engineering Transactions, 2010, vol. 22, pp. 197-202. DOI: 10.3303/CET1022032

8. Drozd V.A., Kholodov A.S., Agoshkov A.I., Petukhov V.I., Blinovskaya Ya.Yu., Lushpey V.P., Vasyanovich Yu.A., Solomennik S.F. [et al.]. Potentional toxic risk from the nano- and microparticles in the atmospheric suspension of Russky Island (Vladivostok). Der Pharma Chemica, 2016, vol. 8, no. 11, pp. 231-235.

9. Baracchini E., Bianco C., Crosera M., Filon F.L., Belluso E., Capella S., Maina G., Adami G. Nano- and Submicron Particles Emission during Gas Tungsten Arc Welding (GTAW) of Steel: Differences between Automatic and Manual Process. Aerosol and Air Quality Research, 2018, vol. 18, no. 3, pp. 579-589. DOI: 10.4209/aaqr.2017.07.0226

10. Penttinen P., Timonen K.L., Tiittanen P., Mirme A., Ruuskanen J.,Pekkanen J. Ultrafine particles in urban air and respiratory health among adult asthmatics. European Respiratory Journal, 2001, vol. 17, no. 3, pp. 428-435. DOI: 10.1183/09031936.01.17304280

11. Simonova I.N., Antonyuk M.V., Vitkina T.I. The influence of nanoparticles from the air on the state of bronchopulmonary system. Byulleten' fiziologii i patologii dykhaniya, 2013, no. 49, pp. 115-120 (in Russian).

12. Zheng W., Antonini J.M., Lin Y.C., Roberts J.R., Kashon M.L., Castranova V., Kan H. Cardiovascular effects in rats after intratracheal instillation of metal welding particles. Inhal Toxicol, 2015, vol. 27, no. 1, pp. 45-53. DOI: 10.3109/08958378.2014.982309

13. Achilleos S., Evans J.S., Yiallouros P.K., Kleanthous S., Schwartz J., Koutrakis P. PM10 concentration levels at an urban and background site in Cyprus: the impact of urban sources and dust storms. J. Air Waste Manag. Assoc, 2014, vol. 64, no. 12, pp. 1352-1360. DOI: 10.1080/10962247.2014.923061

14. Zhang X.-X., Chen X., Wang Z.-F., Guo Y.-H., Li J., Chen H.-S., Yang W.-Y., Sharratt B., Liu L.-Y. Dust deposition and ambient PM10 concentration in Northwest China: spatial and temporal variability. Atmospheric Chemistry and Physics, 2017, vol. 17, no. 3, pp. 1699-1711. DOI: 10.5194/acp-17-1699-2017

15. Prosviryakova I.A., Shevchuk L.M. Hygienic assessment of pm10 and pm2.5 contents in the atmosphere and population health risk in zones infleunced by emissions from stationary sources located at industrial enterprises. Health Risk Analysis, 2018, no. 2, pp. 14-22. DOI: 10.21668/health.risk/2018.2.02.eng (in Russian).

16. Osnovy otsenki riska dlya zdorov'ya naseleniya pri vozdeistvii khimicheskikh veshchestv, zagryaznyayushchikh okruzhayushchuyu sredu [Guidelines on assessment of population health risk under exposure to chemicals which pollute environment]. In: Yu.A. Rakhmanin, G.G. Onishchenko eds. Moscow, Nauchno-issledovatel'skii institute ekologii cheloveka i gigieny okruzhayushchei sredy imeni A.N. Sysina Publ., 2002, 408 p. (in Russian).

17. EH40/2005 Workplace exposure limits. Health and Safety Executive, 2018, vol.3.Available at: http://www.hse.gov.uk/pUbns/priced/eh40.pdf (10.03.2019).

18. Oberdörster G. Pulmonary effects of inhaled ultrafine particles. International Archives of Occupational and Environmental Health, 2001, vol. 74, no. 1, pp. 1-8. 
19. Beattie H., Keen Ch., Coldwell M., Tan E., Morton J., McAlinden J., Smith P. The use of bio-monitoring to assess exposure in the electroplating industry. J. Expo. Sci. Environ. Epidemiol., 2017, vol. 27, no. 1, pp. 47-55. DOI: 10.1038/jes.2015.67

20. Pan C.H., Jeng H.A., Lai C.H. Biomarkers of oxidative stress in electroplating workers exposed to hexavalent chromium. J. Expo. Sci. Environ. Epidemiol., 2018, vol. 28, no. 1, pp. 76-83. DOI: $10.1038 /$ jes.2016.85

21. Guo S., Hu M., Zamora M.L., Peng J., Shang D., Zheng J., Du Zh., Wu Zh. [et al.] Elucidating severe urban haze formation in China. Proceedings of the National Academy of Sciences of the United States of America, 2014, vol. 111, no. 49, pp. 17373-17378. DOI: 10.1073/pnas.1419604111

Golokhvast K.S., Kirichenko K.Yu., Kiku P.F., Efimova N.V., Savchenkov M.F., Vakhnyuk I.A., Kosyanov D.Yu., Medvedev S.A., Soparev V.P., Drozd V.A. Nano- and micro-particles concentrations in working area air at galvanic production: pilot research. Health Risk Analysis, 2019, no. 3, pp. 34-41. DOI: 10.21668/health.risk/2019.3.04.eng

Received: 01.04.2019

Accepted: 08.08.2019

Published: 30.09.2019 